\title{
PELATIHAN PENULISAN ARTIKEL ILMIAH NON PENELITIAN BAGI GURU SEKOLAH DASAR NEGERI GUGUS 2 SEKARBELA MATARAM
}

\author{
Heri Hadi Saputra $^{1 *}$, Safruddin ${ }^{2}$, Husniati $^{3}$ \\ 1, 2, 3 Program Studi PGSD, FKIP, Universitas Mataram \\ *Co-Author :heri_fkip@unram.ac.id
}

\begin{abstract}
ABSTRAK. Penyuluhan yang berjudul pelatihan penulisan artikel ilmiah non penelitian bagi guru SDN gugus 2 sekarbela kota mataram merupakan bagian dari aktivitas pengabdian pada masyarakat yang menjadi salah satu tri dharma perguruan tinggi yang dilaksanakan oleh FKIP universitas mataram bertujuan untuk meningkatkan kompetensi guru dalam menyampaikan gagasan dan pandangan mereka tentang pendidikan melalui tulisan. Adapun tujuannya secra terperinci adalah sebagi berikut : (1) membantu guru menulis gagasan dan pandangan mereka tentang issu-issu pendidikan yang berkembang di masyarakat; (2) membantu guru merancang tulisan-tulisan ilmiah non penelitian yang dapat dipublikasikan di media massa maupun buku; dan (3) membantu guru melahirkan karya tulis yang dapat dibaca dan dijadikan referensi dalam issu-issu pendidikan kontemporer Penyampaian materi dilakukan dengan metode ceramah, diskusi dan tanyajawab serta pemberian latihan singkat tentang kaidah penulisan artikel. Adapun materi yang diberikan yaitu tentang konsep dasar karya tulis ilmiah, perbedaan karya tulis ilmiah penelitian dan non penelitia serta sistematika penulisan artikel ilmiah non penelitian.Tahapan terakhir dari pengadian ini adalah melakukan pendampingan singakt kepada para peserta dalam menemukan ide dan gagasan yang akn dijadikan sebagai bahan tulisan.Dari 28 peserta yang hadir hampir semua memberikan tanggapan yang baik tentang kegiatan ini sehingga menyampaikan harapan untuk diteruskan pada tahapan selanjutnya.
\end{abstract}

Kata Kunci: artikel nonpenelitian, pelatihan, guru sekolah dasar

\begin{abstract}
Counseling titled training in writing non scientific research articles for teachers of SDN cluster 2 Sekarbela mataram city is part of community service activities which are one of the tri dharma of higher education institutions conducted by FKIP mataram university aims to improve teacher competencies in conveying their ideas and views about education through writing. The objectives in detail are as follows: (1) helping teachers write their ideas and views on educational issues developing in the community; (2) helping teachers design non-research scientific writings that can be published in mass media and books; and (3) helping teachers produce written papers that can be read and used as references in contemporary education issues. Submission of material is done by lecturing, discussion and question and answer methods as well as providing brief exercises on the rules of writing articles. The material provided is about the basic concepts of scientific papers, differences in research scientific papers and non-research as well as the systematic writing of non-research scientific articles. The final stage of this event is to provide a brief assistance to the participants in finding ideas and ideas that will be used as material writing. Of the 28 participants who attended, almost all of them gave good responses about this activity so that they expressed their hope to be continued in the next stage.
\end{abstract}

Keywords: non-research articles, training, elementary school teachers 


\section{PENDAHULUAN}

Guru mengemban tanggung jawab akademik untuk mengajar, membimbing, membina dan mendidik siswanya, namun selain itu guru juga memiliki tanggungjawab sosial untuk melakukan pembinaan masyarakat, menyampaikan gagasan-gagasan tentang pendidikan serta menjawab isuisu pendidikan yang beredar dimasyarakat melalui media massa online maupun offline.

Perkembangan teknologi informasi dan komunikasi dewasa ini telah membuka ruang yang sangat lebar untuk tersampaikannya setiap isu dan pandangan masyarakat dalam segala kontek dan permasalahan tanpa bisa di hadang ataupun dikendalikan. Ruang-ruang itu juga diisi oleh permasalahan pendidikan yang memang tidak pernah tuntas diindonesia.

Respon terhadap berbagai isu pendidikan yang hadir diruang media tersebut sangat dibutuhkan guna memberikan penjelasan, klarifikasi maupun solusi terhadap tiap permasalahan yang timbul. Terkadang respon-respon yang muncul justru hadir dari mereka yang tidak faham tentang pendidikan dan bukan dari guru yang menjadi prakstisi pendidikan sehingga tanggapantanggapan yang muncul malah membuat masalah dan isu tersebut menjadi bias dan tidak solutif. keterampilan menulis merupakan suatu keterampilan menuangkan pikiran, gagasan, pendapat tentang sesuatu, tanggapan terhadap suatu pernyataan keinginan, atau pengungkapan perasaan dengan menggunakan bahas tulis. (Rofi'uddin dan Zuhdi 1999)

Berbeda halnya jika tulisan-tulisan tentang pendidikan dimedia massa di tulis oleh para guru, dosen maupun praktisi pendidikan yang lain, maka dapat dipastikan tiap gagasan, jawaban, klarifikasi maupun solusi yang mereka berikan melalui tulisan dapat menjadi kontribusi positif bagi dunia pendidikan indonesia.

Sejauh ini kolom-kolom opini dan tajuk dimedia massa belum banyak diisi oleh tulisan-tulisan yang dibuat oleh para pelaku pendidikan khususnya guru. Hal ini menunjukkan bahwa partisipasi sosial guru khususnya diruang media guna mengkomunikasikan gagasan dan ide mereka tentang pendidikan yang notebena menjadi pekerjaan dan dunia mereka masih sangat rendah. Mereka masih lebih banyak memposisikan disri sebagai konsumen isu dan gagasan orang lain. Yang terjadi justru para guru lebih banyak menyampaikan pandangan-pandangan mereka tentang sebuah isu pendidikan dimasyarakat dalam bentuk obrolan dan pembicaran verbal sesama mereka saja sehingga jangkauan dari perspektif yang mereka hadirkan juga terbatas dikalangan mereka para guru. Menurut tarigan keterampilan menulis adalah salah satu keterampilan berbahasa yang produktif dan ekspresif yang dipergunakan untuk berkomunikasi secara tidak langsung dan tidak secara tatap muka dengan pihak lain. (Tarigan, 2008)

Sesungguhnya para guru diindonesia tidak kekurangan gagasan dalam mengembangkan pendidikan dan pembelajaran. Hal ini dapat dengan mudah dibuktikan dalam tiap perbincangan dengan para guru, dalam menyampaiakan pandangan-pandangan mereka secara verbal, biasanya mereka akan sangat mudah memberikan perspektif dan gagasan-gagasan tentang pendidikan yang menjadi dunia mereka mulai dari aspek pembelajaran, pengembangan karakter, analisa kebijakan bahkan isu tentang tatakelola pendidikan. Namun sekali lagi itu hanya muncul dalam ungkapanungkapan verbal ynag hanya bisa di dengar oleh kalangan tententu dalam kuantitas yang sangat terbatas. 
Media massa seperti koran dan majalah yang menyediakan kolom pendidikan tidak banyak diisi oleh para guru. Kita jarang membaca profil guru berprestasi maupun opini guru tentang pendidikan yang disampaikan pada momen-momen pendidikan seperti hari pendidikan nasional. Justru momen-momen tersebut banyak diisi oleh isu-isu pendidikan yang kontradiktif dan paradok dengan tujuan pendidikan nasional maupun gambar-gambar aktifitas siswa yang terkadang agak melenceng dari karakter pendidikan.

Salah satu kelemahan yang dimiliki oleh para guru adalah kurangnya kemampuan mereka dalam menulis, sehingga perspektif mereka tentang pendidikan tidak tersampaikan secara luas kemasyarakat. Padahal menulis merupakan salah satu keterampilan yang harus dimiliki guru agar mampu mengkomunikasikan gagasan mereka kepada masyarakat sebagai bagian dari partisipasi sosial untuk membangun bangsa. Pada dasarnya setiap guru saat ini telah akrab dengan media sosial dengan segala jenisnya. Hal ini menunjukkan bahwa guru pada dasarnya telah menulis namun isi tulisan mereka lebih banyak yang bersifat intertain dari pada edukasi. Kondisi ini menjadi cerminan jauhnya kaum guru dari identitas sebenarnya yang harus melekat pada diri mereka sebagai edukator.

Asumsi bahwa tulisan harus berbentuk karya ilmiah yang bersumber dari penelitian menjadi salah satu hambatan lahirnya kebiasaan menulis guru padahal sebenarnya mereka dapat menulis ilmiah tanpa harus melakukan penelitian dan hanya menggunakan sumber-sumber yang dapat dipertanggungjawabkan.

Salah satu bentuk pengembangan profesi guru adalah membuat karya tulis ilmiah dibidang pendidikan (harun, 2016) artinya selain sebagai cara memenuhi tanggungkjawab sosial, membuat karya tulis ilmiah juga merupakan bentuk tanggungjawab profesional guru yang mana harus terus dikembangkan agar mereka tidak stagnan dan terhenti pada kemapuan mentransformasi pengetahuan didalam kelas saja. Jika para guru memiliki kemampuan menulis yang baik maka mereka akan mampu menghiasi laman-laman media dengan gagasan dan persfektif pendidikan melaui tulisantulisan yang juga dapat dibaca oleh masyarakat.

\section{PENDEKATAN DAN METODE PELAKSANAAN KEGIATAN}

Kegiatan ini dilaksanakan dengan metode pendampingan (coaching) yang menekankan hubungan kolaboratif antara tim pengabdian kepada masyarakat denagn guru sasaran. Dalam hubungan tersebut tim pengabdian berperan sebagai fasilitator yang bertugas membantu guru untuk mengembangkan outline, membangun issu pokok serta memecahkan masalah dalam menulis. Secara kolaboratif, timpengabdian dan guru bertemu untuk mendiskusikan masalah-masalah yang dihadapi guru dalam menulis serta mencari cara untuk memecahkannya. Secara lebih spesifik tim pengabdian bertugas untuk mengkoordinis pertemuan antar guru, memfasilitasi diskusi dan evaluasi terhadap masalah dalam menulis artikel non penelitian serta menstimulus guru agar mampu melahirkan karya tulis yang dapat dipublikasikan pada media cetak dan buku. Selain itu tim pengabdian berperan untuk memberikan editing dan penajaman gagasan bagi tulisan yang telah dihasilkan guru dalam pelatihan.

Metode pelaksanaan kegiatan ini meliputi, ceramah berbantuan media slide, tanya jawab, diskusi dan kerja individual dalam kelompok. Metode ceramah digunakan untuk menyampaikan pengertian, jenis dan kaidah-kaidah penulisan karya tulis ilmiah. Metode tanya jawab digunakan untuk mengekplorasi pengalaman dan permasalahan-permasalahan yang dihadapi guru dalam 
menulis. Metode diskusi digunakan untuk menstimulasi guru agar mampu melahirkan karya tulis yang bersumber dari issu yang telah dipetakan oleh tim pengabdian. Selain itu metode diskusi juga digunakan untuk menumbuhkan motivasi dan semangat bagi guru agar mampu melahirkan karya tulis bidang pendidikan yng dapat dipublikasikan di media cetak dan buku sebagai kontribusu pemikiran guru bagi masyarakat, pemerintah dan pihak terkait.

\section{HASIL DAN PEMBAHASAN}

pelaksanaan kegiatan dilaksanakan pada hari selasa tanggal 13 november 2018 mulai dari pukul 09.00 sampai pukul 13. 00 Wita. Kegiatan diawali dengan acara pembukaan yang langsung di sampaikan oleh ketua gugus 2 sekarbela yang juga sekaligus kepala SDN No. 41 Ampenan. Dalam sambutan pembukaan ketua gugus 2 sekarbela menyampaikan ungkapan terimakasih kepada tim peneliti karena telah memilih sekolah mereka sebagai lokasi KKM yang memiliki arti bahwa ada perhatian perguruan tinggi dalam hal ini universitas mataram untuk turut serta membina dan meningkatkan kemampuan para guru khususnya digugu 2 sekarbela.

Setelah acara pembukaan selasai kegiatan segera dilanjutkan dengan pemberian materi oleh tim PKM. Pada tahap awal materi disampaikan tentang konsep dasar karya ilmiah oleh Heri Hadi Saputra, M.Pd. dalam materi ini disampaikan latar belakang tujuan serta luaran yang diharapkan oleh tim dalam kegiatan tersebut.

Sesi satu, Selanjutnya heri hadi saputra menyampaikan beberapa fakta terkait dengan minimnya tulisan guru tentang issu pendidikan baik dimedia cetak online maupun offline yang menjadi penanda rendahnya karya tulis guru dalam menyikapi issu pendidikan yang terjadi ditengah masyarkat. Banyak kasus pendidikan yang justru penulisnya bukan para guru yang notebena adalah aktor pendidikan, namun para akademisi serta pengamat yang tulisannya belum tentu bersesuaian dengan fakta pendidikan dilapangan. Selanjutnya materi difokuskan pada konsep dasar karya tulis ilmiah yang berisi : materi penulisan, metode penulisan, inventarisasi ide dan gagasan, memilih ide, ubah ide menjadi topik tulisan, Buat rancangan tulisan, Berdasarkan kerangka tulisan, himpun sumber bacaan yang sesuai, Buat intisari-intisari sumber bacaan yang dapat berupa fakta, data atau informasi, Susun intisari-intisari ke dalam sub judul yang sesuai pada kerangka tulisan, Pengolahan data, fakta atau informasi, Metode analisis dan sintesis, Hasil analisis dan sintesis tersebut disimpulkan yang dapat berupa fakta, data atau informasi, konsep, temuan, ide, gagasan, hipotesis dll., yang berbeda dengan intisari-intisari yang ada di sumber bacaan. (materi terlampir)

Sesi kedua, merupakan penyampaian materi tentang perbedaan karya tulis ilmiah penelitian dan non penelitian yang disampaikan oleh Husniati, M.Pd. dalam pemaparanya disampaikan tentang tentang perbedaan karya tulis ilmiah hasil penelitian dan non penelitian secra substantif.

Sesi tiga, diteruskan oleh Drs. Safruddin, M.Pd. tentang materi sistematika penulisan artikel ilmiah non penelitian yang berisi tentang: judul, nama dan alamat penulis, abstrak dan kata kunci, pendahukluan, bagian inti, penutup dan daftar rujukan

Setelah sesi pemaparan selesai lalu dilanjutkan dengan sesi diskusi dan tanya jawab. Dalam sesi ini para peserta lebih banyak menyampaikan permasalahan mereka dalam menghasilkan karya tulis, kurangnya budaya baca, keluangan waktu yang sdikit serta kurangnya motivasi internal maupun eksternal dianggap sebagai faktor yang menghambat merreka melahirkan karya tulis. 


\section{KESIMPULAN}

Karya tulis ilmiah non penelitian merupakan salah satu penanda kompetensi dan produktifitas guru dalam dunia pendidikan. Banyak issu pendidikan yang seharusnya direspon dan diinisiasi oleh guru justru dilakukan oleh orang lain karena rendahnya kemampuan guru dalam membuat karya tulis. Untuk dapat membuat karya tulis yang baik para guru harus menguasai konsep tentang karya tulis ilmiah, perbedaan hasil penelitian dan non penelitian serta sistematika dan metode penulisan yang benar. Adapaun langkah penyusunan yang harus dilalui berupa menginventarisir materi penulisan, metode penulisan, inventarisasi ide dan gagasan, memilih ide, ubah ide menjadi topik tulisan, Buat rancangan tulisan berdasarkan kerangka tulisan, himpun sumber bacaan yang sesuai, buat intisari-intisari sumber bacaan yang dapat berupa fakta, data atau informasi, Susun intisari-intisari ke dalam sub judul yang sesuai pada kerangka tulisan, Pengolahan data, fakta atau informasi, Metode analisis dan sintesis, Hasil analisis dan sintesis tersebut disimpulkan yang dapat berupa fakta, data atau informasi, konsep, temuan, ide, gagasan, hipotesis. Selain itu para guru membutuhkan pendampingan yang intens dari pihak kampus khususnya para dosen yang sekaligus dapat menjadi inspirator dan motivator bagi mereka untuk melahirkan karya tulis. Sebagai tim pelaksana pengabdian pada masyarakat menyampaikan saran agar peltihan serupa lebih banyak diberikan kepada guru tidak hanya diwilayah perkotan namun juga wilayah pedesaan dengan memperhatikan tahapan penyusunan tulisan mulai tingkat yang paling dasar kepada yang lebih komplek sehingga para guru memiliki kemampuan untuk membuat tulisan populer maupun yang berbasis penelitian. .

\section{UCAPAN TERIMA KASIH}

Tim pengabdian kepada masyarakat mengucapkan terima kasih kepada Universitas Mataran yang telah mendanai kegiatan Pelatihan Penulisan Artikel IImiah Non Penelitian Bagi Guru Sekolah Dasar Negeri Gugus 2 Sekarbela Mataram melalui dana PNBP tahun 2018 dan tim pengabdian yang telah meluangkan waktu dan tenaga hingga selesai laporan dan artikel ini. Ucapan terima kasih juga disampaikan kepada peserta yaitu guru-guru serta kepala SD Negeri Gugus 2 Sekarbela Mataram yang terlibat aktif dan atas kerjasama yang baik dengan tim pengabdian.

\section{REFERENSI}

Adnan, Z. dan Zifirdaus, I. 2005. Merebut Hati Audiens Internasional: Strategi ampuh meraih publikasi di jurnal ilmiah. Jakarta : Gramedia Pustaka Utama.

Aqib, zainal dkk (2008). Karya Tulis Ilmiah. Bandung : Yrama Widya

Dikti. 2008. Pedoman Umum Kompetisi Karya Tulis Mahasiswa (KKTM) Bidang IPA, IPS dan IImu Pendidikan. Jakarta : Dikti, Depdiknas,.

Hanum, Farida (2016) Pedoman Lengkap Membuat Karya Tulis Penelitian Dan Non Penelitian Untuk Guru. Yogyakarta : Araska Publisher.

Kamarudin, Yokee tjuparmah (2000). Kamus Istilah Karya Tulis IImiah. Jakarta : bumi aksara

Mulyono, iyo (2014). Dari Karya Tulis Ilmiah Sampai Soft Skill . bandung, : Yrama Widya.

Rifai, M. A. (1995). Pegangan: Gaya Penulisan, Penyuntingan, dan Penerbitan Karya IImiah Indonesia. UGM Press : Yogyakarta.

Santoso, U. (2008). Tips Praktis Menulis Karya Ilmiah Internasional. Jakarta: Algensindo

Wardani, IGAK dkk (2008). Teknik Menulis karya IImiah. Jakarta : Universitas Terbuka. 